\title{
Update on capecitabine alone and in combination regimens in colorectal cancer patients
}

\author{
N. Silvestris*, E. Maiello ${ }^{\mathrm{b}}$, F. De Vitac , S. Cinieri ${ }^{\mathrm{d}, \mathrm{j}}$, D. Santini ${ }^{\mathrm{e}}$, A. Russof ${ }^{\mathrm{f}}, \mathrm{S}_{\text {. Tommasi }}^{\mathrm{g}}$, A. Azzariti ${ }^{\mathrm{g}}$, \\ G. Numico ${ }^{h}$, S. Pisconti ${ }^{i}$, D. Petriella ${ }^{g}$, V. Lorusso ${ }^{k}$, A. Millakul ${ }^{1}$ G. Coluccia \\ ${ }^{a}$ Medical and Experimental Oncology Unit, Cancer Institute "Giovanni Paolo II", Bari, Italy \\ ${ }^{b}$ Medical Oncology Unit, Hospital "Casa Sollievo della Sofferenza", San Giovanni Rotondo, Italy

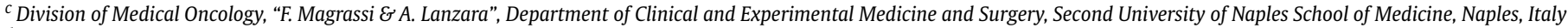 \\ ${ }^{d}$ Medical Oncology Unit, Hospital Perrino, Brindisi, Italy \\ ${ }^{e}$ Medical Oncology Unit, University Campus Biomedico, Rome, Italy \\ ${ }^{f}$ Genetic and Molecular Oncology Unit, University of Palermo, Italy \\ g Clinical and Experimental Laboratory, Cancer Institute "Giovanni Paolo II", Bari, Italy \\ ${ }^{h}$ Medical Oncology Unit, Hospital Parrini, Aosta, Italy \\ ${ }^{i}$ Medical Oncology Unit, Hospital Moscati, Taranto, Italy \\ ${ }^{j}$ Medical Department, Istituto Europeo di Oncologia Milano, Italy \\ ${ }^{k}$ Medical Oncology Unit, Hospital Vito Fazzi, Lecce, Italy \\ ${ }^{\prime}$ UCCK University Clinical Center of Kosovo, Prishtine, Kosovo
}

\section{A R T I C L E I N F O}

\section{Keywords:}

Capecitabine

Colorectal carcinoma

Adjuvant

Neoadjuvant

Metastatic

Radiotherapy

Oxaliplatin

Irinotecan

Cetuximab

Bevacizumab

\section{S U M M A R Y}

Capecitabine is an orally administered fluoropyrimidine carbamate which has been developed as a prodrug of 5-FU with the goal to improve its tolerability and intratumoral drug concentration. The review aims to provide an evidence-based update of clinical trials investigating the clinical efficacy, adverse-event profile, dosage and administration of this drug, alone or in combination with conventional chemotherapeutics and/or new target-oriented drugs, in the management of colorectal cancer patients.

(c) 2010 Elsevier Ltd. All rights reserved.

\section{Introduction}

5-fluorouracil (5-FU) has been the cornerstone of chemotherapy for the past 50 years in the treatment of metastatic colorectal carcinoma (mCRC). We know from several studies and metaanalyses that its combination with leucovorin (LV) improves outcome in terms of response rate (RR) and survival. ${ }^{1}$ It has also been demonstrated that continuous-infusion 5-FU/LV is better than bolus intravenous injection of $5-\mathrm{FU} .^{2}$ Even with the recent introduction of new cytotoxic agents (eg, irinotecan and oxaliplatin) and targeted therapies such as bevacizumab, cetuximab, and panitumumab, 5-FU remains a key component of most recommended chemotherapy regimens. One potential drawback of 5-FU is its poor oral absorption, which requires a permanent venous access and a portable pump and might cause complications.

\footnotetext{
* Corresponding author. Nicola Silvestris, MD. Medical and Experimental Oncology Unit, Cancer Institute "Giovanni Paolo II", Via Hahnemann, 1070125 Bari, Italy.

Tel.: +39080 5555240; fax: +390805555232.

E-mail address: n.silvestris@oncologico.bari.it (N. Silvestris).
}

Capecitabine is an orally administered prodrug of 5-FU that is absorbed readily by the gastrointestinal tract with a bioavailability of almost $100 \%$. The maximum plasma concentration (Cmax) and area under the plasma concentration-time curve are linearly proportional to the oral dosage. In fact, after a standard single dose of capecitabine $\left(1250 \mathrm{mg} / \mathrm{m}^{2}\right)$, the $\mathrm{Cmax}$ is achieved in 1.5-2 hours. Capecitabine is metabolized by the liver, where it is converted initially to 5'-deoxy-5-fluorocytidine and subsequently, to 5'-deoxy-5-fluorouridine (5'-DFUR). Finally, 5'-DFUR is converted to 5-FU by thymidine phosphorylase (TP), which is present in amounts 3- to 10-fold higher in neoplastic tissue compared with the normal adjacent tissue (Fig. 1). The higher concentration of TP in tumor tissues leads to a final concentration of 5-FU that is 3-fold higher than in normal tissues. ${ }^{3}$

\section{Capecitabine as single agent in $\mathrm{mCRC}$}

Phase I-II trials conducted in MCRC patients defined the recommended daily dose of capecitabine, which is $1250 \mathrm{mg} / \mathrm{m}^{2}$ bis in die (bid) for two consecutive weeks, and one week rest, repeating this treatment every 3 weeks. ${ }^{4}$ Two phase III randomized 


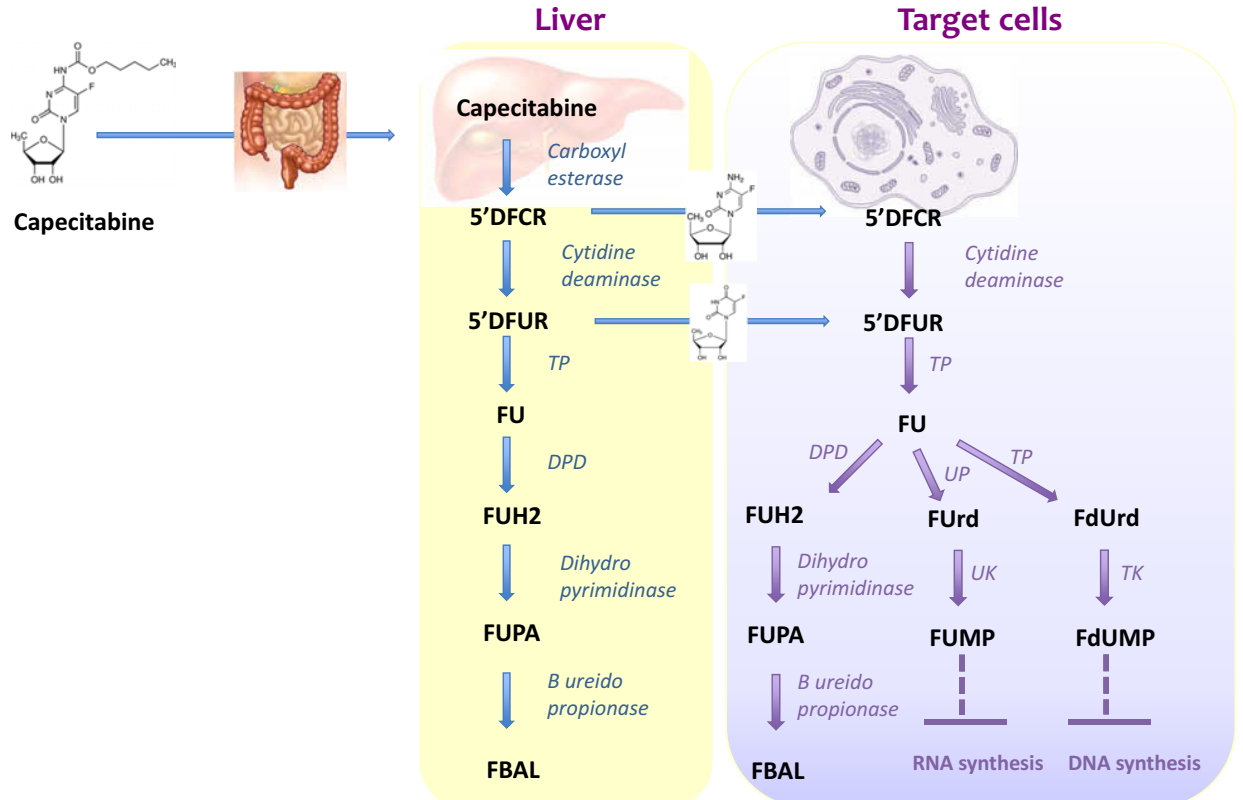

Fig. 1. Stages in the metabolism of capecitabine.

Table 1

Randomized phase III trials comparing capecitabine with 5-FU/LV (Mayo Clinic) in mCRC

\begin{tabular}{|c|c|c|c|c|c|c|}
\hline Author & Regimen & No. of patients & ORR (\%) & median TTP (months) & median OS (months) & G3-4 toxicity \\
\hline \multirow[t]{2}{*}{ Hoff et al. ${ }^{5}$} & Capecitabine & 302 & 25.8 & 4.3 & 12.5 & HFS: $18 \%$; Stomatitis: $3 \%$ \\
\hline & versus & & $p<0.05$ & & & \\
\hline \multirow[t]{2}{*}{ Van Cutsem et al. ${ }^{6}$} & $\begin{array}{l}\text { Capecitabine } \\
\text { versus }\end{array}$ & 301 & 18.9 & 5.2 & 13.2 & HFS: $16.2 \%$; Stomatitis: $1.3 \%$ \\
\hline & 5-FU/LV & 301 & 15 & 4.7 & 12.1 & HFS: $0.3 \%$; Stomatitis: $13.3 \%$ \\
\hline
\end{tabular}

trials compared capecitabine with the Mayo Clinic regimen in this subset of patients (Table 1). ${ }^{5,6}$ Both studies met their primary end point, which was to demonstrate at least statistical equivalence between the 2 regimens, while objective response rates (ORRs) were significantly improved for capecitabine, and significant differences in toxicity were noted. In particular, in a pooled comparison of safety parameters from these 2 phase III trials, the safety profile of capecitabine was superior to that of $5-\mathrm{FU} / \mathrm{LV}$, with significantly $(\mathrm{p}<0.001)$ less diarrhea, stomatitis, nausea, alopecia, and grade $3 / 4$ neutropenia. ${ }^{7}$ In contrast, capecitabine was associated with a higher incidence of hand and foot syndrome (HFS) (53.5\% versus $6.2 \%$ ) and hyperbilirubinemia (G3: $18.3 \%$ versus $3.3 \%$ ), which was typically unconiugated bilirubin. Most patients required no dose reductions, moreover, a dose modification scheme reduced the incidence of several toxicities without compromising the efficacy. Given its good toxicity profile, capecitabine has been assessed in a phase II trial for the treatment of elderly (aged $\geq 70$ years) mCRC patients. ${ }^{8}$ Authors observed an ORR of $24 \%$ with a median time to progression (TTP) and overall survival (OS) of 7 months and 11 months, respectively. Capecitabine was extremely well tolerated with grade $\geq 3$ adverse events occurring in only $12 \%$ of patients.

\section{Capecitabine in combination regimens in MCRC}

Given the activity of single-agent capecitabine versus 5-FU/LV for mCRC, multiple studies have evaluated capecitabine in combination with other agents in this subset of patients.

\section{Capecitabine plus oxaliplatin}

Two different schedules compare capecitabine and oxaliplatin. The XELOX regimens include oxaliplatin $130 \mathrm{mg} / \mathrm{m}^{2}$ on day 1 every 3 weeks, whereas CAPOX regimens split the oxaliplatin dose to $70 \mathrm{mg} / \mathrm{m}^{2}$ on days 1 and 8 . Capecitabine $1000 \mathrm{mg} / \mathrm{m}^{2}$ bid is given for 2 consecutive weeks with 1 week rest. Early phase II trials considering XELOX and CAPOX regimens achieved promising ORRs of $37-55 \%$, median TTP of $6-8$ months, and median OS of 16-20 months (Table 2) with feasible and safe toxicity profiles. $^{9-13}$ Recently, Maiello et al. reported preliminary results of a phase II trial considering an innovative schedule considering a biweekly administration of oxaliplatin and capecitabine (XELOX-2). ${ }^{14}$ Preliminary results showed that this combination is active and well tolerated with only one patient presented G4 toxicity (diarrhea).

On the basis of this background, some randomized studies were conducted in order to show at least non inferiority and allowing for the substitution of capecitabine for continuous-infusion 5-FU/LV (Table 3). One of the first trials to compare capecitabine/oxaliplatin was the TREE (Three Regimens of Eloxatin Evaluation)- 1 trial. ${ }^{15}$ This study was initially designed to investigate the role of oxaliplatin in the first-line treatment for mCRC patients with three different fluoropyrimidine regimens: modified FOLFOX6, bFOL, or XELOX. ORR was $43 \%, 22 \%$ and $35 \%$ respectively, while median TTP was 8.7, 6.9 and 5.9 months, and median OS was 19.2, 17.9 and 17.2 months. The investigators observed that XELOX caused an inacceptable occurrence of severe dehydration (27\%) in comparison with FOLFOX6 (8\%) or bFOL (12\%). The worse tolerability of capecitabine in US patients, as opposed to patients treated in other 
Table 2

Capecitabine plus oxaliplatin in the first line setting of mCRC: results from phase II studies

\begin{tabular}{|c|c|c|c|c|c|}
\hline Author & No. of patients & Regimen & ORR (\%) & median TTP (months) & median OS (months) \\
\hline Borner et al. ${ }^{9}$ & 43 & XELOX & 49 & 5.9 & 17.1 \\
\hline Cassidy et al. ${ }^{10}$ & 96 & XELOX & 55 & 7.7 & 19.5 \\
\hline Grothey et al. ${ }^{11}$ & 71 & CAPOX & 49 & 6.6 & 15.8 \\
\hline Shields et al. ${ }^{12}$ & 35 & XELOX & 37 & 6.9 & NA \\
\hline Zeuli et al. ${ }^{13}$ & 43 & XELOX & 44 & 8.2 & 20 \\
\hline Fedele et al. ${ }^{14}$ (GOIM 2503) & 51 & XELOX-2 & 51 & $5+$ & NA \\
\hline
\end{tabular}

NA: not available

XELOX: oxaliplatin $130 \mathrm{mg} / \mathrm{m}^{2}$ on day 1 and capecitabine $1000 \mathrm{mg} / \mathrm{m}^{2}$ bid on days $1 \rightarrow 14 \mathrm{q} 3 \mathrm{w}$

CAPOX: oxaliplatin $70 \mathrm{mg} / \mathrm{m}^{2}$ on days 1 and 8 and capecitabine $1000 \mathrm{mg} / \mathrm{m}^{2}$ on days $1 \rightarrow 14 \mathrm{q} 3 \mathrm{w}$

XELOX-2: oxaliplatin $100 \mathrm{mg} / \mathrm{m}^{2}$ on day 1 and capecitabine $1000 \mathrm{mg} / \mathrm{m}^{2}$ bid on days $1 \rightarrow 7 \mathrm{q} 2 \mathrm{w}$

Table 3

Oxaliplatin plus capecitabine versus oxaliplatin plus 5-FU/LV: results of phase III studies

\begin{tabular}{|c|c|c|c|c|c|c|c|}
\hline Author & Regimen & $\begin{array}{l}\text { Line of } \\
\text { therapy }\end{array}$ & $\begin{array}{l}\text { No. of } \\
\text { patients }\end{array}$ & ORR (\%) & $\begin{array}{l}\text { medianTTP } \\
\text { (month) }\end{array}$ & $\begin{array}{l}\text { medianOS } \\
\text { (month) }\end{array}$ & G3-4 toxicity \\
\hline \multirow[t]{3}{*}{$\begin{array}{l}\text { Hochster et al. }{ }^{15} \\
\text { (TREE-1 trial) }\end{array}$} & $\begin{array}{l}\text { mFOLFOX6 } \\
\text { versus }\end{array}$ & I & 49 & 41 & 8.7 & 19.2 & Less neutropenia (15\%) but more dehydration (27\%) with XELOX \\
\hline & $\begin{array}{l}\text { bFOL } \\
\text { versus }\end{array}$ & & 50 & 20 & 6.9 & 17.9 & \\
\hline & XELOX & & 48 & 27 & 5.9 & 17.2 & \\
\hline \multirow[t]{2}{*}{$\begin{array}{l}\text { Cassidy et al. }{ }^{16} \\
\text { (N016966 trial) }\end{array}$} & $\begin{array}{l}\text { XELOX } \\
\text { versus }\end{array}$ & I & 317 & 37 & 7.3 & NA & More diarrhea (20\%) and HFS (6\%) with XELOX \\
\hline & FOLFOX4 & & 317 & 39 & 7.7 & NA & \\
\hline \multirow[t]{2}{*}{ Porschen et al. ${ }^{17}$} & $\begin{array}{l}\text { CAPOX } \\
\text { versus }\end{array}$ & I & 241 & 48 & 7.1 & 16.8 & More HFS (10\%) with CAPOX \\
\hline & FUFOX & & 233 & 54 & 8 & 18.8 & \\
\hline \multirow[t]{2}{*}{ Díaz-Rubio et al. ${ }^{18}$} & $\begin{array}{l}\text { XELOX } \\
\text { versus }\end{array}$ & I & 171 & 37 & 8.9 & 18.1 & Less diarrhea (14\%) with XELOX \\
\hline & FUOX & & 171 & 46 & 9.5 & 20.8 & \\
\hline \multirow[t]{2}{*}{ Rothenberg et al. ${ }^{19}$} & $\begin{array}{l}\text { XELOX } \\
\text { versus }\end{array}$ & II & 627 & 20 & 4.8 & 11.9 & $\begin{array}{l}\text { Lower neutropenia (5\%) but more diarrhea (20\%) and HFS (3.5\%) } \\
\text { with XELOX }\end{array}$ \\
\hline & FOLFOX4 & & & 18 & 4.7 & 12.6 & \\
\hline
\end{tabular}

bFOL: oxaliplatin $85 \mathrm{mg} / \mathrm{m}^{2}$ on day 1 and 5 -FU $500 \mathrm{mg} / \mathrm{m}^{2}$ plus LV $20 \mathrm{mg} / \mathrm{m}^{2}$ on days 1 and $8 \mathrm{q} 2 \mathrm{w}$

CAPOX: capecitabine $1000 \mathrm{mg} / \mathrm{m}^{2}$ bid on days $1 \rightarrow 14$ and oxaliplatin $70 \mathrm{mg} / \mathrm{m}^{2}$ on days 1 and $8 \mathrm{q} 3 \mathrm{w}$

XELOX: capecitabine $1000 \mathrm{mg} / \mathrm{m}^{2}$ bid on days $1 \rightarrow 14$ and oxaliplatin $130 \mathrm{mg} / \mathrm{m}^{2}$ on day $1 \mathrm{q} 3 \mathrm{w}$

FUFOX: oxaliplatin $50 \mathrm{mg} / \mathrm{m}^{2}$, LV $500 \mathrm{mg} / \mathrm{m}^{2}$ and 5 -FU $2000 \mathrm{mg} / \mathrm{m}^{2}$ over 24 hours weekly for 4 weeks and 2 weeks of rest

FUOX: continuous infusion 5-FU $2250 \mathrm{mg} / \mathrm{m}^{2}$ over 48 hours weekly for 6 weeks plus oxaliplatin $85 \mathrm{mg} / \mathrm{m}^{2}$ every other week

mFOLFOX6: oxaliplatin $85 \mathrm{mg} / \mathrm{m}^{2}$ plus LV $300 \mathrm{mg} / \mathrm{m}^{2}$, 5-FU $500 \mathrm{mg} / \mathrm{m}^{2}$ bolus and 5-FU 240046 -hour infusion on day $1 \mathrm{q} 2 \mathrm{w}$

FOLFOX4: oxaliplatin $85 \mathrm{mg} / \mathrm{m}^{2}$ on day $1, \mathrm{LV} 200 \mathrm{mg} / \mathrm{m}^{2}, 5-\mathrm{FU} 400 \mathrm{mg} / \mathrm{m}^{2}$ bolus and 5-FU $600 \mathrm{mg} / \mathrm{m}^{2}$ over 22 hours on days 1 and 2 q w 2

countries, has been attributed to the difference in dietary intake of folic acid due to the vitamin enrichment of fruit in North America. ${ }^{20}$ After 150 patients had been enrolled, data regarding bevacizumab efficacy became available. At that point trial was amended, and 213 more patients were randomized to the same arms plus bevacizumab $(2.5 \mathrm{mg} / \mathrm{kg} /$ week $)$. Indeed, dosage of capecitabine in the XELOX regimen was decreased to $1750 \mathrm{mg} / \mathrm{m}^{2}$ for 2 weeks. In comparison with the TREE- 1 study, addition of bevacizumab was reported to improve the efficacy in all arms. In fact, ORR, mPFS and mOS were 53\%, 9.9 months, and 26 months on FOLFOX plus bevacizumab; 41\%, 8.3 months, and 20.7 months on bFOL plus bevacizumab arm; 48\%, 10.3 months, and 27 months on XELOX plus bevacizumab arm. The second and largest reported randomized phase III trial (NO16966) compared FOLFOX4 with XELOX. ${ }^{16}$ This study accrued 634 patients and was then amended with the addition of bevacizumab when it became registered for first-line therapy. Actually, the non inferiority of the XELOX versus FOLFOX4 regimen was demonstrated, because the TTP was 8 months versus 8.5 months. Additionally, XELOX reduced the incidence of grade $\geq 3$ neutropenia ( $7 \%$ versus $44 \%$ ), but produced more severe diarrhea (20\% versus $11 \%$ ) than the FOLFOX regimen. Bevacizumab did not increase the ORR of either XELOX or FOLFOX4, but significantly prolonged the median TTP in comparison with placebo ( 8 months versus 9.4 months; $\mathrm{p}=0.0023$ ). ${ }^{21}$ Porschen et al. compared the FOLFOX regimen with the CAPOX regimen. ${ }^{17}$ No significant differences in ORR, median TTP or median OS were reported for the two arms of the study. Tolerance profiles again showed that both regimens had an acceptable toxicity rate, with a higher incidence of HFS in the CAPOX arm. Diaz-Rubio et al. compared FUOX with XELOX. ${ }^{18}$ Although patients treated with the XELOX regimen had a lower ORR, the median TTP and OS were not significantly different. Capecitabine treatment was associated with more HFS (10\%). A pooled of six trials comparing oxaliplatincapecitabine versus oxaliplatin-5-FU as first line therapy of mCRC, including 3,494 patients, showed that the ORR was significantly higher for 5-FU based regimens, but this did not affect TTP and OS, which were similar in both treatment arms. ${ }^{22}$ The toxicity analysis showed the characteristic toxicity of each of the different 5-FU schedules, with thrombocytopenia and HFS consistently more prominent in the capecitabine regimens. 
Table 4

Capecitabine plus irinotecan in first-line treatment of mCRC: results of phase II/III studies

\begin{tabular}{|c|c|c|c|c|c|c|c|}
\hline Author & Phase & $\begin{array}{l}\text { No. of } \\
\text { patients }\end{array}$ & Regimen & $\begin{array}{l}\text { ORR } \\
(\%)\end{array}$ & $\begin{array}{l}\text { Median } \\
\text { TTP } \\
\text { (months) }\end{array}$ & $\begin{array}{l}\text { Median } \\
\text { OS } \\
\text { (months) }\end{array}$ & G3-4 toxicity \\
\hline Cartwright et al. ${ }^{24}$ & II & 49 & $\begin{array}{l}\text { XELIRI (irinotecan } 240 \mathrm{mg} / \mathrm{m}^{2} \text { on day } 1 \text { and capecitabine } 1000 \mathrm{mg} / \mathrm{m}^{2} \text { bid } \\
\text { on days } 1 \rightarrow 14 \mathrm{q} 3 \mathrm{w} \text { ) }\end{array}$ & 45 & 6.2 & 13.4 & $\begin{array}{l}\text { Diarrhea: } 20 \% \\
\text { Neutropenia: } 12 \% \\
\text { Dehydration: } 10 \%\end{array}$ \\
\hline Patt et al. ${ }^{25}$ & II & 52 & $\begin{array}{l}\text { CAPIRI (irinotecan } 250 \mathrm{mg} / \mathrm{m}^{2} \text { on day } 1 \text { and capecitabine } 1000 \mathrm{mg} / \mathrm{m}^{2} \text { bid } \\
\text { on days } 1 \rightarrow 14 \mathrm{q} 3 \mathrm{w} \text { ) }\end{array}$ & 46 & 7.1 & 15.6 & $\begin{array}{l}\text { Neutropenia: } 25 \% \\
\text { Diarrhea: } 20 \% \\
\text { Dehydration: } 10 \%\end{array}$ \\
\hline Rea et al. $^{26}$ & $\mathrm{I} / \mathrm{II}$ & 57 & $\begin{array}{l}\text { XELIRI (irinotecan } 250 \mathrm{mg} / \mathrm{m}^{2} \text { on day } 1 \text { and capecitabine } 1000 \mathrm{mg} / \mathrm{m}^{2} \text { bid } \\
\text { on days } 1 \rightarrow 14 \mathrm{q} 3 \mathrm{w} \text { ) }\end{array}$ & 42 & 8.3 & - & $\begin{array}{l}\text { Diarrhea was the most } \\
\text { common serious } \\
\text { toxicity }\end{array}$ \\
\hline \multirow[t]{2}{*}{ Bajetta et al. ${ }^{27}$} & $\begin{array}{l}\text { II } \\
\text { randomized }\end{array}$ & 68 & $\begin{array}{l}\text { CAPIRI (irinotecan } 150 \rightarrow 120 \mathrm{mg} / \mathrm{m}^{2} \text { on days } 1 \text { and } 8 \text { and capecitabine } \\
1250 \rightarrow 1000 \mathrm{mg} / \mathrm{m}^{2} \text { bid on days } 2 \rightarrow 15 \mathrm{q} 3 \mathrm{w} \text { ) } \\
\text { versus }\end{array}$ & 44 & 7.6 & - & Diarrhea: $16 \% \rightarrow 37 \%$ \\
\hline & & 66 & $\begin{array}{l}\text { XELIRI (irinotecan } 300 \rightarrow 240 \mathrm{mg} / \mathrm{m}^{2} \text { on day } 1 \text { and capecitabine } \\
1250 \rightarrow 1000 \mathrm{mg} / \mathrm{m}^{2} \text { bid on days } 2 \rightarrow 15 \mathrm{q} 3 \mathrm{w} \text { ) }\end{array}$ & 47 & 8.3 & & Diarrhea: $35 \% \rightarrow 25 \%$ \\
\hline \multirow[t]{2}{*}{ Borner et al. ${ }^{28}$} & $\begin{array}{l}\text { II } \\
\text { randomized }\end{array}$ & 37 & $\begin{array}{l}\text { CAPIRI (irinotecan } 70 \mathrm{mg} / \mathrm{m}^{2} \text { on days } 1,8,15,22,29 \text { and capecitabine } \\
1000 \mathrm{mg} / \mathrm{m}^{2} \text { bid on days } 1 \rightarrow 14 \mathrm{q} 3 \mathrm{w} \text { ) } \\
\text { versus }\end{array}$ & 34 & 6.9 & 17.4 & $\begin{array}{l}\text { Diarrhea: } 34 \% \\
\text { Neutropenia: } 5 \%\end{array}$ \\
\hline & & 38 & $\begin{array}{l}\text { XELIRI (irinotecan } 300 \rightarrow 240 \mathrm{mg} / \mathrm{m}^{2} \text { on day } 1 \text { and capecitabine } \\
1000 \mathrm{mg} / \mathrm{m}^{2} \text { on days } 1 \rightarrow 14 \mathrm{q} 3 \mathrm{w} \text { ) }\end{array}$ & 25 & 9.2 & 24.7 & $\begin{array}{l}\text { Diarrhea: } 19 \% \\
\text { Neutropenia: } 19 \%\end{array}$ \\
\hline \multirow[t]{2}{*}{$\begin{array}{l}\text { Colucci et al. } \\
\text { (GOIM 2405) }^{29}\end{array}$} & $\begin{array}{l}\text { II } \\
\text { randomized }\end{array}$ & 95 & $\begin{array}{l}\text { FOLFIRI (irinotecan } 180 \mathrm{mg} / \mathrm{m}^{2} \text { on day } 1 \text {, leucovorin } 100 \mathrm{mg} / \mathrm{m}^{2} \text { and } 5 \text {-FU } \\
\text { bolus } 400 \mathrm{mg} / \mathrm{m}^{2} \text { on days } 1 \text { and } 2,5 \text {-FU } 600 \mathrm{mg} / \mathrm{m}^{2} \text { continuous infusion } \\
\text { on days } 1 \text { and } 2 \text { q } 2 \mathrm{w} \text { ) } \\
\text { versus }\end{array}$ & 32 & 6.5 & 24.6 & $\begin{array}{l}\text { Neutropenia: } 16 \% \\
\text { Diarrhea: } 3 \%\end{array}$ \\
\hline & & & $\begin{array}{l}\text { XELIRI (irinotecan } 250 \mathrm{mg} / \mathrm{m}^{2} \text { on day } 1 \text { and capecitabine } 1000 \mathrm{mg} / \mathrm{m}^{2} \text { bid } \\
\text { on days } 1 \rightarrow 14 \mathrm{q} 3 \mathrm{w} \text { ) }{ }^{\mathrm{a}}\end{array}$ & 48 & 8.7 & 26.5 & $\begin{array}{l}\text { Neutropenia: } 17 \% \\
\text { Diarrhea: } 12 \%\end{array}$ \\
\hline $\begin{array}{l}\text { Kohne et al. }{ }^{30} \\
\text { (EORTC 40015) }\end{array}$ & $\begin{array}{l}\text { III } \\
\text { (suspended) }\end{array}$ & 43 & $\begin{array}{l}\text { XELIRI (irinotecan } 250 \mathrm{mg} / \mathrm{m}^{2} \text { on day } 1 \text { and capecitabine } 1000 \mathrm{mg} / \mathrm{m}^{2} \text { bid } \\
\text { on days } 1 \rightarrow 14 \mathrm{q} 3 \mathrm{w} \text { ) } \\
+/ \text { - CELECOXIB }(800 \mathrm{mg} / \mathrm{die})\end{array}$ & $\begin{array}{l}22- \\
48\end{array}$ & 5.9 & 14.8 & $\begin{array}{l}\text { Six deaths with XELIRI } \\
\text { and } 2 \text { with FOLFIRI }\end{array}$ \\
\hline $\begin{array}{l}\text { Fuchs et al. }{ }^{31} \\
\text { (BICC-C) }\end{array}$ & III & 145 & $\begin{array}{l}\text { XELIRI (irinotecan } 250 \mathrm{mg} / \mathrm{m}^{2} \text { on day } 1 \text { and capecitabine } 1000 \mathrm{mg} / \mathrm{m}^{2} \text { bid } \\
\text { on days } 1 \rightarrow 14 \mathrm{q} 3 \mathrm{w} \text { ) }\end{array}$ & 38 & 5.5 & 18.9 & $\begin{array}{l}\text { Diarrhea: } 47 \% \\
\text { Neutropenia: } 32 \%\end{array}$ \\
\hline $\begin{array}{l}\text { Koopman et al. }{ }^{32} \\
\text { (CAIRO) }\end{array}$ & III & 398 & $\begin{array}{l}\text { XELIRI (irinotecan } 250 \mathrm{mg} / \mathrm{m}^{2} \text { on day } 1 \text { and capecitabine } 1000 \mathrm{mg} / \mathrm{m}^{2} \text { bid } \\
\text { on days } 1 \rightarrow 14 \mathrm{q} 3 \mathrm{w} \text { ) }\end{array}$ & 41 & 7.8 & 17.4 & $\begin{array}{l}\text { Diarrhea: } 26 \% \\
\text { Neutropenia: } 7 \%\end{array}$ \\
\hline
\end{tabular}


bid, respectively).

A phase III trial was conducted to demonstrate the non-inferiority of the XELOX versus the FOLFOX4 regimen in 627 patients who had received a prior treatment with irinotecan. ${ }^{19}$ The non-inferiority of the XELOX in terms of TTP and OS was proven even if it was associated with a greater incidence of severe diarrhea and HFS.

In amulticenter, randomized, phase III study Tabernero et al. evaluated the efficacy and tolerability of 6 cycles of bevacizumab $\left(7.5 \mathrm{mg} / \mathrm{kg}\right.$ ) plus XELOX (capecitabine $1000 \mathrm{mg} / \mathrm{m}^{2}$ on days $1 \rightarrow 14$ and oxaliplatin $130 \mathrm{mg} / \mathrm{m}^{2}$ on day 1 every 3 weeks) followed by XELOX/bevacizumab ( $a r m \mathrm{~A}$ ) or single-agent bevacizumab (arm B). ${ }^{23}$ After a follow up of 16 months, there were not statistically differences in ORR, TTP, and OS between the 2 arms. Preliminary analysis of safety showed that tolerability was acceptable in the 2 arms, with G3-4 diarrhea in $11 \%$ and $13 \%$, HFS in $12 \%$ and $6 \%$, and neuropathy in $24 \%$ and $7 \%$ in arms A and B, respectively.

\section{Capecitabine plus irinotecan}

Different schedules combining capecitabine and irinotecan were evaluated in phase II trials. Administration of irinotecan 100$150 \mathrm{mg} / \mathrm{m}^{2}$ on days 1 and 8 or weekly irinotecan $70 \mathrm{mg} / \mathrm{m}^{2}$ (CAPIRI) was compared with the application of irinotecan at higher doses only at day 1 every 3 weeks (XELIRI) (Table 4). ${ }^{24-28}$ In particular, Bajetta et al. allocated 140 patients to receive capecitabine plus irinotecan either on day $1(\operatorname{arm} A)$ or on days 1 and $8(\operatorname{arm~B})$, every 3 weeks. ${ }^{27}$ After a reduction of dosages of irinotecan and capecitabine, diarrhea was registred in $26 \%$ of patients in arm A, and in $38 \%$ of patients in arm B; ORR and TTP were comparable. Similarly, two dosages of irinotecan (weekly or every 3 weeks) in combination with capecitabine were evaluated by Borner et al.. ${ }^{28}$ ORR was comparable with the 2 regimens even if mTTP and mOS were both in favor of the arm with irinotecan every 3 weeks, which also caused less $\geq 3$ diarrhea.

In summary, data of these trials were encouraging with ORR of XELIRI or CAPIRI of 34-47\%, TTP of 6-9 months, and OS of 13-25 months, respectively. Nevertheless, irinotecan and capecitabine displayed partly overlapping adverse events, particularly with respect to gastrointestinal toxicity. In fact, up to $36 \%$ of patients in these studies developed $\geq$ grade 3 gastrointestinal toxicity, and many patients required dose modification. ${ }^{33}$

Definitive results of a phase II randomized trial of Gruppo Oncologico dell'Italia Meridionale (GOIM)

From July 2005 to August 2008 a multicenter randomized phase II study was conducted by GOIM (protocol n.2405) to evaluate both efficacy and tolerability of FOLFIRI and XELIRI in chemo-naïve patients with mCRC. ${ }^{29}$ Arm A (FOLFIRI) regimen consisted of irinotecan $180 \mathrm{mg} / \mathrm{m}^{2}$ on day 1 with $\mathrm{LV} 100 \mathrm{mg} / \mathrm{m}^{2}$ administered as a 2-hours infusion before 5 -FU $400 \mathrm{mg} / \mathrm{m}^{2}$ administered as an 
Table 5

Recommended dose modifications with capecitabine monotherapy

\begin{tabular}{lll}
\hline Toxicity NCIC grade & During a course of therapy & Dose adjustment for the next treatment \\
\hline Grade 1 & Maintain dose level & Maintain dose level \\
Grade 2 & & $100 \%$ of starting dose \\
First appearance & Interruption until G0-1 & $75 \%$ of starting dose \\
Second appearance & Interruption until G0-1 & $50 \%$ of starting dose \\
Third appearance & Interruption until G0-1 & - \\
Fourth appearance & Permanent interruption & $75 \%$ of starting dose \\
Grade 3 & & $50 \%$ of starting dose \\
First appearance & Interruption until G0-1 & - \\
Second appearance & Interruption until G0-1 & Eventually 50\% of starting dose \\
Third appearance & Permanent interruption & \\
Grade 4 & & \\
First appearance & Permanent interruption, or if patient's best interest is to continue, & \\
\hline
\end{tabular}

intravenous bolus injection; 5-FU $600 \mathrm{mg} / \mathrm{m}^{2}$ was administered as a 22-hours infusion immediately after 5-FU bolus injection. LV and 5-FU were repeated on days 1 and 2 every 2 weeks. Arm B (XELIRI) consisted of irinotecan $250 \mathrm{mg} / \mathrm{m}^{2}\left(200 \mathrm{mg} / \mathrm{m}^{2}\right.$ for patients $\geq 70$ years) only on day 1 , with capecitabine $1000 \mathrm{mg} / \mathrm{m}^{2}$ bid ( $750 \mathrm{mg}\left(\mathrm{m}^{2}\right.$ bid for patients $>70$ years) on days $1-14$ every 3 weeks. A total of 95 consecutive patients were assessable for response. ORR in arms A and B were $32.2 \%$ and $48.4 \%$ respectively. By adding up ORR plus stable disease, the tumor growth control rate was $80.6 \%$ and $85.9 \%$, respectively. Median TTP was 6.5 months and 8.7 months in arms A and B, respectively. Overall, the majority of adverse events in both arms were mild or moderate and gastrointestinal or myeloid in nature. In particular, the most common grade 3 or 4 treatmentrelated events were leuko/neutropenia (3.2/16.1\% versus $7.8 / 17.2 \%$ in arms $A$ and $B$, respectively) and diarrhea $3.2 \%$ versus $12.5 \%$ in arms $A$ and $B$, respectively). Only one case of G3 HFS was reported in the XELIRI arm. Dose reduction due to adverse events was required in $15 \%$ of patients in the FOLFIRI arm and $21 \%$ of patients in the XELIRI arm. There were no treatment-related deaths during the study.

\section{Phase III trials}

The EORTC 40015 study was the first phase III trial aiming to randomize 692 patients in a $2 \times 2$ factorial design to receive XELIRI versus FOLFIRI with or without the cyclooxygenase- 2 inhibitor celecoxib. ${ }^{30}$ This trial had to be suspended after the accrual of 85 patients $(n=43$ for XELIRI) because of 8 fatal events unrelated to disease progression ( 6 in XELIRI arm and 2 in the FOLFIRI arm). In addition, $61 \%$ of patients starting the XELIRI treatment required dose reduction as opposed to only $7 \%$ in the FOLFIRI arm. Due to the small sample size following early termination, no definitive conclusions can be drawn in relation to the non inferiority of XELIRI compared with FOLFIRI. A second randomized phase III trial (BICC-C) evaluated FOLFIRI versus modified IFL versus XELIRI with or without celecoxib and randomized 145 patients into the XELIRI arm. ${ }^{31}$ There was a trend toward higher ORR and improved OS for FOLFIRI compared with the MIFL and XELIRI arms. The addition of celecoxib did not affected activity and toxicity of each regimen. However, XELIRI regimen produced an unacceptably higher occurrence of severe diarrhea and dehydration (48\% and $19 \%$ ) than either FOLFIRI (13\% and $6 \%$ ) or mIFL (19\% and $7 \%$ ). This observation led to the closure of this arm in the trial. Today, the largest cohort of patients $(n=398)$ with XELIRI first-line treatment for mCRC was the CAIRO (CApecitabine, IRinotecan, Oxaliplatin) trial investigating sequential versus combination chemotherapy in a phase III setting (arm A: capecitabine $\rightarrow$ irinotecan $\rightarrow$ XELOX; arm B: XELIRI $\rightarrow$ XELOX). ${ }^{32}$ In arm B, ORR (41\% versus $20 \%, \mathrm{p}=0.0001$ ) and TTP (7.8 versus 5.8 months, $\mathrm{p}=0.0002$ ) were significantly improved, but the difference in OS was not significant (17.4 versus 16.3 months). The following grade $\geq 3$ toxicity were reported with XELIRI: 26\% diarrhea, 10\% nausea, $7 \%$ febrile neutropenia, and 6\% HFS. The investigators observed that the overall incidence of ischemic and thromboembolic events were comparable and low in both arms. ${ }^{34}$ As a consequence, the negative results of the EORTC 40015 and the BICC-C trials were not confirmed in this much larger cohort of patients receiving XELIRI.

A phase III randomized study compared XELIRI plus bevaciuzmab versus FOLFIRI plus bevacizumab as first line treatment in $\mathrm{MCRC}$ patients. ${ }^{35}$ After a median follow up of 28.7 months, the trial did not show significant differences in efficacy between the two arms. Most frequent G3-4 toxicities were neutropenia (12\% versus $22 \%$ ) and diarrhea (18\% versus $11 \%$ ).

\section{Special considerations with XELIRI}

Patients receiving XELIRI regimen need to be informed in details about the possibility of delayed diarrhea and measures to be taken, including the potential consequences of not communicating these events with the physician and nursing staff. Indeed, doses of irinotecan and capecitabine need to be adjusted in case of liver or renal dysfunction, and doses have to be reduced in presence of $\geq$ grade 3 gastrointestinal toxicity. ${ }^{36}$ In particular, guidelines for capecitabine dose modification/interruption have been developed, and they should be used when trying to optimize oral fluoropyrimidine therapy for patients with mCRC (Table 5).

\section{Capecitabine in the adjuvant treatment of CRC}

Oral chemotherapies may be advantageous in the adjuvant setting because of their easy administration and patient preference. ${ }^{37}$ Based of its successful use in patients with metastatic disease, capecitabine was also studied in the adjuvant setting.

The Capecitabine Adjuvant Chemotherapy for Colon Cancer Trial (X-ACT) was conducted to assess the equivalence for disease-free survival (DFS) between 5-FU/LV therapy (Mayo Clinic) and oral capecitabine $\left(1250 \mathrm{mg} / \mathrm{m}^{2}\right.$ twice daily, from day 1 to 14 , every 3 weeks), both for 6 months in patients with resected stage III CRC. ${ }^{38}$ At 3 years disease free survival (DFS) was significantly superior $(p=0.0407)$, and OS rates showed also a trend toward superiority in favour of capecitabine $(71.4 \%$ versus $68.4 \%, \mathrm{HR}=0.84$, 
Table 6

Single agent capecitabine in the neoadjuvant treatment of rectal cancer

\begin{tabular}{|c|c|c|c|c|c|}
\hline \multirow[t]{2}{*}{ Author } & \multirow{2}{*}{$\begin{array}{l}\text { Phase (No. of } \\
\text { patients) }\end{array}$} & \multicolumn{2}{|l|}{ Treatment } & \multirow[t]{2}{*}{ Disease response } & \multirow[t]{2}{*}{ G3-4 toxicity } \\
\hline & & Chemotherapy & Total RT dose & & \\
\hline Dunst et al. ${ }^{46}$ & I (36) & Capecitabine $250-1000 \mathrm{mg} / \mathrm{m}^{2}$ bid (MTD: $825 \mathrm{mg} / \mathrm{m}^{2}$ bid) & $50.4 \mathrm{~Gy}$ & $10 \%$ ypCR & Diarrhea: $3 \%$ \\
\hline Ngan et al. ${ }^{47}$ & I (28) & Capecitabine $425-100 \mathrm{mg} / \mathrm{m}^{2}$ bid 5 days qw (MTD: $900 \mathrm{mg} / \mathrm{m}^{2}$ bid) & $50.4 \mathrm{~Gy}$ & $\begin{array}{l}56 \% \text { tumor downstaging } \\
19 \% \text { ypCR }\end{array}$ & Diarrhea: $4 \%$ \\
\hline Kim et al. ${ }^{48}$ & II (45) & $\begin{array}{l}\text { Capecitabine } 825 \mathrm{mg} / \mathrm{m}^{2} \text { bid on days } 1-14 \mathrm{q} 3 \mathrm{w} \times 2 \text { cycles and } \\
\text { Leucovorin } 20 \mathrm{mg} / \mathrm{m}^{2} / \text { die on days } 1-14 \mathrm{q} 3 \mathrm{w} \times 2 \text { cycles }\end{array}$ & $50.4 \mathrm{~Gy}$ & $\begin{array}{l}84 \% \text { tumor downstaging } \\
31 \% \text { ypCR }\end{array}$ & $\begin{array}{l}\text { HFS: } 7 \% \\
\text { Diarrhea: } 4 \% \\
\text { Fatigue: } 4 \%\end{array}$ \\
\hline De Paoli et al. ${ }^{49}$ & II (54) & $\begin{array}{l}\text { Capecitabine } 825 \mathrm{mg} / \mathrm{m}^{2} \text { bid with RT } \\
\text { followed by resection followed by } \\
\text { Capecitabine } 1250 \mathrm{mg} / \mathrm{m}^{2} \text { bid on days } 1-14 \mathrm{q} 3 \mathrm{w} \times 4 \text { cycles }\end{array}$ & $\begin{array}{l}52.5 \mathrm{~Gy} \\
\text { (last } 5 \text { fractions bid) }\end{array}$ & $\begin{array}{l}59 \% \text { tumor downstaging } \\
18 \% \text { ypCR }\end{array}$ & $\begin{array}{l}\text { Diarrhea: } 2 \% \\
\text { Proctitis: } 4 \%\end{array}$ \\
\hline Krishnan et al. ${ }^{50}$ & II (54) & $\begin{array}{l}\text { Capecitabine } 825 \mathrm{mg} / \mathrm{m}^{2} \text { bid followed by resection followed by } \\
\text { Capecitabine } 1250 \mathrm{mg} / \mathrm{m}^{2} \text { bid on days } 1-14 \mathrm{q} 3 \mathrm{w} \times 4 \text { cycles }\end{array}$ & $52.2 \mathrm{~Gy}$ & $\begin{array}{l}59 \% \text { tumor downstaging } \\
18 \% \text { ypCR }\end{array}$ & $\begin{array}{l}\text { Diarrhea: } 2 \% \\
\text { Proctitis: } 4 \%\end{array}$ \\
\hline Chan et al. ${ }^{51}$ & $\begin{array}{l}\text { Retrospective } \\
\text { analysis } \\
\text { (34 versus } 68 \text { ) }\end{array}$ & $\begin{array}{l}\text { Capecitabine } 825 \mathrm{mg} / \mathrm{m}^{2} \text { bid } 5 \text { days qw versus } \\
5 \text {-FU } 20 \mathrm{mg} / \mathrm{kg} / \mathrm{die}, \mathrm{LV} 200 \mathrm{mg} / \mathrm{m}^{2} \text { on days } 1-4 \text { and Mytomicin C } \\
8 \mathrm{mg} / \mathrm{m}^{2} \text { on day } 1\end{array}$ & $50 \mathrm{~Gy}$ & $\begin{array}{l}59 \% \text { tumor downstaging } \\
\text { in both groups; } \\
21 \% \text { versus } 18 \% \text { ypCR }\end{array}$ & $\begin{array}{l}\text { Diarrhea: } \\
3 \% \text { versus } 1 \%\end{array}$ \\
\hline
\end{tabular}

$\mathrm{p}=0.0706$ ). The incidence of diarrhea, nausea/vomiting, stomatitis, neutropenia, and alopecia was significantly less in the capecitabibe group, whereas HFS occurred more frequently in the arm receiving capecitabine. This drug has, however, never been tested against continuous-infusion 5-FU, which is known to provide better RRs and improved tolerances compared with bolus 5-FU/LV. Recently, Dimovski et al. evaluated the predictive value of TS promoter, MTHFR C667T, MSI and/or 18qLOH markers on efficacy/toxicity of adjuvant capecitabine monotherapy in 142 CRC patients. ${ }^{39}$ The authors observed that MSI+ and MTHFR677TT genotype are predictive of mid-term relapse-free survival of colon cancer patients treated with this drug.

XELOX as adjuvant therapy for stage III CRC has been tested by comparing 5-FU/LV (either Mayo Clinic or Rosweel Park regimens). The planned safety analysis comprised 1.864 patients, of whom 938 received XELOX and 926 received 5-FU/LV. Occurrence of grade $\geq 3$ toxicity was in favour of the XELOX regimen for febrile neutropenia ( $0.2 \%$ versus $3.8 \%$ ) and severe stomatitis ( $0.6 \%$ versus $7.9 \%$ ); nevertheless, the XELOX produced more skin (3.6\% versus $0.2 \%$ ) and neurosensory ( $8.1 \%$ versus $0 \%$ ) toxicity. ${ }^{40}$ With a median follow up of 57 months, patients treated with XELOX had a 3-year DFS significantly higher than patients treated with 5-FU/LV (71\% versus $67 \%, p=0.0045) .{ }^{41}$ Additionally, efficacy benefits seemed to be maintained in patients $\geq 70$ years. ${ }^{42}$

\section{Capecitabine in the neoadjuvant treatment of rectal cancer}

Preoperative chemoradiotherapy (CRT) has become the standard of care for patients with T3-4 rectal cancers after a randomized trial by the German Rectal Cancer Study Group comparing preoperative with postoperative CRT and using conventional fractionation and continuous infusion 5-FU at weeks 1 and 5 along with 4 months of adjuvant 5-FU chemotherapy. ${ }^{43}$ The results of this study provided a similar OS rate but a lower rate of local recurrence and toxicity for patients with locally advanced rectal cancer.

Capecitabine can be given on a daily basis to approximate infusional administration and it potentially achieves the described benefits of 5 -FU infusion in conjunction with RT. ${ }^{44}$ Indeed, preclinical studies suggest that capecitabine may offer greater synergy with radiotherapy, as shown by the enhanced TP expression in human colorectal tumor cell line xenografts treated with RT in preclinical studies. ${ }^{45}$

\section{Single agent capecitabine}

Two phase I dose-finding studies investigated the feasibility of using concurrent RT and capecitabine and defined the maximum tolerated dose (MTD). ${ }^{46,47}$ In both studies the MTD of the drug was found to be $1000 \mathrm{mg} / \mathrm{m}^{2}$ bid. As a result, the recommended dose of capecitabine with RT is $825 \mathrm{mg} / \mathrm{m}^{2}$ bid administered from the first to the last day of standard pelvic RT.

Several phase II studies have evaluated the combination of capecitabine $825 \mathrm{mg} / \mathrm{m}^{2}$ bid with preoperative RT in this subset of patients (Table 6). Kim et al. administered two cycles of capecitabine and LV (20 mg/m²/daily) for 14 days, followed by a 7-day rest, during pelvic RT; they reported a tumor downstaging in $63 \%$ and a ypCR in $31 \%$ of patients. ${ }^{48}$ No grade $\geq 3$ hematologic toxicity was registered, while severe diarrhea affected $4 \%$ of patients. In another study capecitabine given continuously during pelvic RT achieved a ypCR in $24 \%$ of patients with only 6 (11\%) patients suffering from grade 3 toxicity. ${ }^{49}$ Krishnan et al. delivered the same combination of capecitabine and pelvic RT and achieved 9 (24\%) ypCR with 12 (24\%) patients showing microscopic residual disease. ${ }^{50}$ Diarrhea occurred in $2 \%$ of patients. Chan et al. compared in a retrospective case-matching study preoperative RT with capecitabine versus preoperative RT with intermittent 5-FU infusion, $\mathrm{LV}$, and mytomicin $\mathrm{C}$ and observed a comparable pathologic tumor response between the two arms of treatment. ${ }^{51}$ Hofhneinz et al. reported preliminary results of a phase III trial comparing capecitabine with 5-FU as neoadjuvant or adjuvant chemotherapy associated with RT. ${ }^{52}$ Authors observed, in the neoadjuvant setting, that capecitabine achieved a non-significant higher rate of tumor-downstaging (52\% versus 39\%) and N0 (71\% versus 56\%) than 5-FU. Furthermore, a lower incidence of leucopenia (25\% versus 35\%) but more HFS (31\% versus $2 \%$ ) were reported in the arm with capecitabine.

In summary, the results of these studies suggest that the response rates with capecitabine CRT are similar or better than those achieved with intravenous 5-FU.

\section{Capecitabine in combination regimens}

Irinotecan has radiosensitizing effects ${ }^{53}$ but, unlike oxaliplatin, it has not been shown to improve DFS in the adjuvant treatment of colon cancer when added to 5-FU. Capecitabine and weekly irinotecan during pelvic RT were assessed by Klautke et al. in a phase I/II trial with a ypCR in $19 \%$ of patients. ${ }^{54}$ Grade 3 diarrhea was the most common toxicity, reported in $37 \%$ of patients. In a 
Table 7

Capecitabine in combination regimens in the neoadjuvant treatment of rectal cancer

\begin{tabular}{|c|c|c|c|c|c|}
\hline \multirow[t]{2}{*}{ Author } & Phase & Treatment & & \multirow[t]{2}{*}{ Disease response } & \multirow{2}{*}{ G3-4 toxicity } \\
\hline & $\begin{array}{l}\text { (No. of } \\
\text { patients) }\end{array}$ & Chemotherapy & $\begin{array}{l}\text { Total } \\
\text { RT dose }\end{array}$ & & \\
\hline
\end{tabular}

\section{Irinotecan}

Klautke et al. ${ }^{54}$

I/II (28) Capecitabine $500-25 \mathrm{mg} / \mathrm{m}^{2}$ bid (MTD: $750 \mathrm{mg} / \mathrm{m}^{2}$ ) and Irinotecan $40 \mathrm{mg} / \mathrm{m}^{2} \mathrm{qw} \times 6$

Willeke et al. ${ }^{55}$

II (36) Capecitabine $500 \mathrm{mg} / \mathrm{m}^{2}$ bid and

Irinotecan $50 \mathrm{mg} / \mathrm{m}^{2} \mathrm{qw}$

\section{Oxaliplatin}

Rödel et al. ${ }^{58}$

I/II (32) Capecitabine $825 \mathrm{mg} / \mathrm{m}^{2}$ bid days $1-14$ and $22-35$ and Oxaliplatin $50-60 \mathrm{mg} / \mathrm{m}^{2}$ days $1,8,22$, and 29 (MTD: $50 \mathrm{mg} / \mathrm{m}^{2}$ )

Glynne-Jones et al. ${ }^{59}$ I (18) Capecitabine $500-825 \mathrm{mg} / \mathrm{m}^{2}$ bid (MTD: $725 \mathrm{mg} / \mathrm{m}^{2}$ ) and Oxaliplatin $130 \mathrm{mg} / \mathrm{m}^{2}$ days 1 and 29

Machiels et al. ${ }^{60}$
Chua et al. ${ }^{61}$
Rödel et al. ${ }^{62}$
Gerard et al. ${ }^{63}$
Target therapies

Czito et al. ${ }^{64}$

Capecitabine $625-825 \mathrm{mg} / \mathrm{m}^{2}$ bid 5 days qw and Bevacizumab $15 \mathrm{mg} / \mathrm{kg}$ day 1 and $10 \mathrm{mg} / \mathrm{kg}$ days 8 and 22 and Oxaliplatin $50 \mathrm{mg} / \mathrm{m}^{2}$

Velenik et al. ${ }^{65}$

Bevacizumab $5 \mathrm{mg} / \mathrm{kg}$ q2 $\mathrm{w}$ before neoadjuvant CRT followed by Bevacizumab $5 \mathrm{mg} / \mathrm{kg}$ on weeks 3,5 , and 7 and Capecitabine $825 \mathrm{mg} / \mathrm{m}^{2}$ bid during RT

Machiels et al. ${ }^{66}$

I/II (40) Capecitabine $650-825 \mathrm{mg} / \mathrm{m}^{2}$ daily days 1-33 (MTD: $825 \mathrm{mg} / \mathrm{m}^{2}$ ) and Cetuximab $400 \mathrm{mg} / \mathrm{m}^{2} 7$ days before initiation of RT, $250 \mathrm{mg} / \mathrm{m}^{2} \mathrm{qw} \times 5$

Hofheinz et al. ${ }^{67}$

Capecitabine $400-500 \mathrm{mg} / \mathrm{m}^{2}$ bid days $1-38$ and Irinotecan $40-50 \mathrm{mg} / \mathrm{m}^{2}$ weekly $\times 5$ and

Cetuximab $400 \mathrm{mg} / \mathrm{m}^{2}$ day 1 and $250 \mathrm{mg} / \mathrm{m}^{2}$ days $8,15,22$, and 29 (MTD: Capecitabine $500 \mathrm{mg} / \mathrm{m}^{2}$ bid, Irinotecan $40 \mathrm{mg} / \mathrm{m}^{2}$ )

Rödel et al. ${ }^{68}$

$\mathrm{I} / \mathrm{II}$ (60) Capecitabine $500-825 \mathrm{mg} / \mathrm{m}^{2}$ bid days $1-24$ and $22-35$ (MTD: $825 \mathrm{mg} / \mathrm{m}^{2}$ ) and 50.4 Oxaliplatin $50 \mathrm{mg} / \mathrm{m}^{2}$ days $1,8,22$, and 29 and Cetuximab $400 \mathrm{mg} / \mathrm{m}^{2} 7$ days before initiation of RT, $250 \mathrm{mg} / \mathrm{m}^{2} \mathrm{qw} \times 6$

50.4 Gy 64\% tumor downstaging Diarhhea: $39 \%$ $36 \%$ ypCR

50.4 Gy 55\% tumor downstaging Diarrhea: 4\% $57 \%$ ypCR Leukopenia: $19 \%$

50.4 Gy 55\% tumor downstaging Diarrhea: 32\% $19 \%$ ypCR

$50.4 \mathrm{~Gy} \quad 72 \%$ tumor downstaging Diarrhea: $11 \%$ $28 \%$ ypCR

45 Gy 53\% tumor downstaging Diarrhea: $30 \%$ $14 \%$ ypCR

54 Gy $\quad 89 \%$ tumor downstaging Diarrhea: $3 \%$ $24 \%$ ypCR

50.4 Gy $16 \%$ ypCR

Diarrhea: $12 \%$ Leukopenia: $4 \%$

45 Gy

versus

50 Gy
yPCR $13.9 \%$ versus $19.2 \%$ Diarrhea:

$3.2 \%$ versus $12.6 \%$
$50.482 \%$ tumor downstaging Diarrhea: $27 \%$ $18 \%$ ypCR Dehydration: $18 \%$

$50.4 \quad 32 \%$ tumor downstaging Diarrhea: $3.8 \%$ $16 \%$ ypCR Proteinuria: $7.7 \%$

$45 \mathrm{~Gy} \quad 38 \%$ tumor downstaging Diarrhea: $15 \%$ 5\% ypCR Dermatitis: $8 \%$

$50.4 \mathrm{~Gy} \quad 42 \%$ tumor downstaging Diarrhea: $20 \%$ $25 \%$ ypCR

47\% tumor downstaging Diarrhea: $19 \%$ $9 \%$ ypCR Leukopenia: $4 \%$ subsequent phase II study Willeke et al. administered a lower dose of capecitabine and reported a ypCR in $14 \%$ of patients with $11 \%$ of grade 3 diarrhea. ${ }^{55}$

The concurrent administration of oxaliplatin with concurrent capecitabine and RT has been most widely studied to date. In part, this is a consequence of oxaliplatin radiosensitizing effect ${ }^{56}$ and its demonstrated benefit in terms of DFS in conjunction with adjuvant 5-FU for resected, locally advanced colon cancer. ${ }^{57}$ Phase I studies have found the MTD of oxaliplatin to be $50 \mathrm{mg} / \mathrm{m}^{2}$ weekly ${ }^{58}$ or $130 \mathrm{mg} / \mathrm{m}^{2}$ every 3 weeks, ${ }^{59}$ when administered with capecitabine $\left(725-825 \mathrm{mg} / \mathrm{m}^{2}\right.$ bid) and $50.4 \mathrm{~Gy}$ of RT. Indeed, oral capecitabine in combination with oxaliplatin and pelvic RT has been shown to be effective and well tolerated in several phase II studies, resulting in
pCR in $10-28 \%$ of patients (Table 7$)^{60-62}$ even if the administration of oxaliplatin was associated with a lightly higher risk of toxicity, including diarrhea and neurotoxicity. It should be observed that the unpredictable rate of toxic deaths (5\%) observed by Chua et al. ${ }^{55}$ prompted authors to modify the eligibility criteria with the exclusion of patients with coronary disease or arhytmia, even when controlled with medications. Following the protocol amendment for cardiovascular safety, only one further thromboembolic event was reported. The authors concluded that intensification of systemic therapy with neoadjuvant CRT before standard treatment is feasible in poor-risk potentially operable rectal cancer, with acceptable safety and promising long-term outcomes. Disappointing results have been reported by in a phase III trial by Gerard et al.. ${ }^{63}$ Authors 
randomly assigned 598 patients to receive 5 weeks of treatment with RT with concurrent capecitabine or RT with capecitabine and oxaliplatin. The oxaliplatin arm was shown to significantly increase (25\% versus $11 \%$ ) the occurrence of grade $\geq 3$ toxicity of the preoperative treatment, and produced a non-significant greater ypCR (19.2\% versus 13.9\%), thus suggesting that this drug should not be used with concurrent RT.

\section{Capecitabine and target therapies}

Target therapy against vascular endothelial growth factor receptor (bevacizumab) $^{64,65}$ and epidermal growth factor (cetuximab) ${ }^{66-69}$ have been studied more recently. In particular, in a phase I study 11 patients received capecitabine, oxaliplatin and bevacizumab concurrently with RT. ${ }^{64}$ Dose level 2 was associated with unacceptable toxicity (primarly diarrhea). The recommended phase II dose was bevacizumab $15 \mathrm{mg} / \mathrm{kg}$ day $1+10 \mathrm{mg} / \mathrm{kg}$ days 8 and 22 , oxaliplatin $50 \mathrm{mg} / \mathrm{m}^{2}$ weekly, and capecitabine $625 \mathrm{mg} / \mathrm{m}^{2}$ bid during radiation days. Interim results of a phase II trial evaluating the combination of capecitabine, RT and bevacizumab have been recently reported. ${ }^{65}$ Authors observed that this schedule is safe and feasible with a promising (16\%) ypCR.

More trials evaluated the role of cetuximab in this subset of patients. In fact, the overexpression of EGFR has been reported to be associated with tumor resistance to local RT. ${ }^{69}$ These data represent a strong rationale for combining cetuximab with preoperative RT for rectal cancer. A phase I-II study showed that the addition of weekly cetuximab to capecitabine given during pelvic RT was feasible, with a grade 3 diarrhea occurring in $15 \%$ of patients, even if the ypCR rate (5\%) was disappointing. ${ }^{67}$ Other authors reported on the feasibility of weekly cetuximab with capecitabine and irinotecan ${ }^{66}$ or oxaliplatin. ${ }^{68}$ However, these studies provided a surprising low rate of $y p C R$ when compared to those previously reported with the same regimens without cetuximab. In summary, the addition of cetuximab to fluoropyrimidine-based CRT schedules suggest an overall pooled ypCR of $9.1 \%$, compared with an overall ypCR rate of $13.5 \%$ seen with fluoropyrimidine-based chemoradiation schedules. ${ }^{70}$ Cetuximab, if delivered concurrently with RT, could potentially abolish additive effects of 5-FU, by inhibiting proliferation. Preclinical data suggests that the sequencing of chemoradiotherapy, EGFR inhibition and RT may be clinically significant. ${ }^{71}$ In addition, the proportion of patients with rectal cancer with mutant K-RAS varies between $30 \%$ and $40 \%{ }^{72}$ In a preoperative chemoradiation study using cetuximab, K-RAS mutant type was found in $9 / 39$ patients $(23 \%){ }^{73}$ Only one $(11 \%)$ of these patients demonstrated a good pathologic regression compared with $11 / 30$ (37\%) patients with K-RAS wild type. As a consequence, more rationally designed preclinical and translational studies (with recognised negative predictive factors) might therefore help select out inappropriate patients.

\section{Conclusions}

The introduction of capecitabine in the treatment of CRC patients represents an important step toward offering patients an easier application of therapy requiring fewer admissions to hospital and leading to higher quality of life for many patients. The combination of capecitabine with oxaliplatin has proven to be non inferior in several phase III clinical trials and could be a substitute for continuous-infusion 5-FU/LV/oxaliplatin. The addition of bevacizumab to the XELOX regimen is safe and effective in mCRC. Indeed, capecitabine could replace bolus or continuousinfusion 5-FU as the standard combination partner for RT in the neoadjuvant treatment of rectal cancer. XELIRI regimen achieves promising efficacy data even if, owing to the partly overlapping gastrointestinal toxicity of capecitabine and irinotecan, patients must be aware of measures to be taken if delayed diarrhea occurs. Furthermore, known risk factors, such as age and the degree of renal impairment, if present, should be taken into consideration when selecting the starting dose of capecitabine. Lastly, from an economic perspective, cost-effectiveness analyses suggested that, despite higher acquisition costs, capecitabine is more cost-effective than standard i.v. treatment. ${ }^{74}$

\section{Acknowledgements}

AA would like to thank Ettore Fistola and Daniele Rizzi for technical help.

\section{Conflict of interests}

All authors declare the absence of conflicts of interest.

\section{References}

1. Thirion P, Michiels S, Pignon JP, et al. Modulation of fluorouracil by leucovorin in patients with advanced colorectal cancer: an updated meta-analysis. MetaAnalysis Group in Cancer. J Clin Oncol 2004;18:3766-75.

2. Meta-Analysis Group in Cancer. Toxicity of fluorouracil in patients with advanced colorectal cancer: effect of administration schedule and prognostic factors. J Clin Oncol 1998;16:3537-41.

3. Miwa $M$, Ura $M$, Nishida $M$, et al. Design of a novel oral fluoropyrimidine carbamate, capecitabibe, which generates 5-fluorouracil selectively in tumours by enzymes concentrated in human liver and cancer tissue. Eur J Cancer 1998;38:1274-81.

4. Van Cutsem E, Findlay M, Osterwalder B, et al. Capecitabine, an oral fluoropyrimidine carbamate with substantial activity in advanced colorectal cancer: results of a randomized phase II study. J Clin Oncol 2000;18:1337-45.

5. Hoff PM, Ansari R, Batist G, et al. Comparison of oral capecitabine versus intravenous fluorouracil plus leucovorin as first-line treatment in 605 patients with metastatic colorectal cancer: results of a randomized phase III study. J Clin Oncol 2001;19:2282-92.

6. Van Cutsem E, Twelves C, Cassidy J, et al. Oral capecitabine compared with fluorouracil plus leucovorin in patients with metastatic colorectal cancer: results of a large phase III study. J Clin Oncol 2001;19:4097-106.

7. Twelves C. Capecitabine as first-line treatment in colorectal cancer. Pooled data from two large, phase III trials. Xeloda Colorectal Cancer Group. Eur J Cancer 2002;38:15-20

8. Feliu J, Escudero P, Llosa F, et al. Capecitabine as first-line treatment for patients older than 70 years with metastatic colorectal cancer: an oncopaz cooperative group study. J Clin Oncol 2005;23:3104-11.

9. Borner MM, Dietrich D, Stupp R, et al. Phase II study of capecitabine plus oxaliplatin compared with fluorouracile and leucovorin plus oxaliplatin in first- and second line treatment of advanced or metastic colorectal cancer. J Clin Oncol 2002;20:1759-66.

10. Cassidy J, Tabernero J, Twelves C, et al. XELOX (capecitabine plus oxaliplatin): active first-line therapy for patient with metastatic colorectal cancer. J Clin Oncol 2004;22:2084-91.

11. Grothey A, Jordan K, Kellner O, et al. Randomized phase II trial of capecitabine plus irinotecan (CapIri) vs capecitabine plu oxaliplatin (CapOx) as first-line therapy of advanced colorectal cancer. Proc Am Soc Clin Oncol 2003;22:255 [abstract 1022]).

12. Shields AF, Zaupski MM, Marshall JL, et al. Treatment of advanced colorectal carcinoma with oxaliplatin and capecitabine: a phase II trial. Cancer 2004; 100 : 531-7.

13. Zeuli M, Nardoni C, Pino MS, et al. Phase II study of capecitabine and oxaliplatin as first-line treatment in advanced colorectal cancer. Ann Oncol 2003; $14: 1378-82$.

14. Fedele P, Di Maggio G, Leo S, et al. Bi-weekly administration of capecitabine + oxaliplatin (XELOX-2) in first-line treatment of advanced colorectal cancer: a phase II study of the Gruppo Oncologico dell'Italia Meridionale (GOIM). Proc Am Soc Clin Oncol 2009;27: Abstr. 15066.

15. Hochster HS, Hart LL, Ramanathan RK, et al. Safety and efficacy of oxaliplatin and fluoropyrimidine regimens with or without bevacizumab as first-line treatment of metastatic colorectal cancer: results of the TREE study. J Clin Oncol 2008;26: 3523-9.

16. Cassidy J, Clarke S, Díaz-Rubio E, et al. Randomized phase III study of capecitabine plus oxaliplatin compared with fluorouracil/folinic acid plus oxaliplatin as first-line therapy for metastatic colorectal cancer. J Clin Oncol 2008;26:2006-12.

17. Porschen R, Arkenau HT, Kubicka S, et al. Phase III study of capecitabine plus oxaliplatin compared with fluorouracil and leucovorin plus oxaliplatin in metastatic colorectal cancer: a final report of the AIO Colorectal Study Group. J Clin Oncol 2007;25:4217-23. 
18. Díaz-Rubio E, Tabernero J, Gómez-España A, et al. Phase III study of capecitabine plus oxaliplatin compared with continuous-infusion fluorouracil plus oxaliplatin as first-line therapy in metastatic colorectal cancer: final report of the Spanish Cooperative Group for the Treatment of Digestive Tumors Trial. J Clin Oncol 2007;25:4224-30.

19. Rothenberg ML, Cox JV, Butts C, et al. Capecitabine plus oxaliplatin (XELOX) versus 5-fluorouracil/folinic acid plus oxaliplatin (FOLFOX-4) as second-line therapy in metastatic colorectal cancer: a randomized phase III noninferiority study. Ann Oncol 2008;19:1720-6.

20. Haller DG, Cassidy J, Clarke SJ, et al. Potential regional differences for the tolerability profiles of fluoropyrimidines. J Clin Oncol 2008;26:2118-23.

21. Saltz LB, Clarke S, Díaz-Rubio E, et al. Bevacizumab in combination with oxaliplatin-based chemotherapy as first-line therapy in metastatic colorectal cancer: a randomized phase III study. J Clin Oncol 2008;26:2013-9.

22. Arkenau HT, Arnold D, Cassidy J, et al. Efficacy of oxaliplatin plus capecitabine or infusional fluorouracil/leucovorin in patients with metastatic colorectal cancer: a pooled analysis of randomized trials. J Clin Oncol 2008;26:5910-7.

23. Tabernero J, Aranda E, Gomez, et al. Phase III study of first-line XELOX plus bevacizumab (BEV) for 6 cycles followed by XELOX plus BEV or single-agent (s/a) BEV as maintenance therapy in patients (pts) with metastatic colorectal cancer (mCRC): The MACRO Trial (Spanish Cooperative Group for the Treatment of Digestive Tumors): Proc Am Soc Clin Oncol 2010;28:7s [abstract 3501].

24. Cartwright T, Lopez T, Vukeija SJ, et al. Results of a phase II open-label study of capecitabine in combination with irinotecan as first-line treatment of metastatic colorectal carcinoma. Clin Colorectal Cancer 2005;5:50-6.

25. Patt Y, Lin E, Liebmann J, et al. Capecitabine plus 3-weekly irinotecan (XELIRI regimen) as first-line chemotherapy for metastatic colorectal cancer: phase II trial results. Am J Clin Oncol 2007;30:350-7.

26. Rea Dw, Nortier JW, Ten Bokkel Huinink WW. A phase I/II and a pharmacokinetic study of irinotecan combined with capecitabine as first-line therapy for advanced colorectal carcinoma. Ann Oncol 2005;16:1123-32.

27. Bajetta E, Di Bartolomeo M, Mariani, et al. Randomized multicenter phase II trial of two different schedules of irinotecan combined with capecitabine as first-line treatment of metastatic colorectal carcinoma. Cancer 2004;100:279-87.

28. Borner MM, Bernhard J, Dietrich D, et al. A randomized phase II trial of capecitabine and two different schedules of irinotecan to first-line treatment of metastatic colorectal cancer: efficacy, quality of life and toxicity. Ann Oncol 2005; $16: 282-8$.

29. Giuliani F, De Vita F, Maiello E, et al. Folfiri versus Xeliri in untreated advanced colorectal cancer: a phase II randomised trial of the Gruppo Oncologico dell'Italia Meridionale (prot. GOIM 2405). EJC Suppl 2008;6:120.

30. Kohne $\mathrm{CH}$, De Greve J, Hartmann JT, et al. Irinotecan combined with infusional 5-fluorouracil/folinic acid or capecitabine plus celecoxib or placebo in the firstline treatment of patients with metastatic colorectal cancer. EORTC study 40015. Ann Oncol 2008;19:920-6.

31. Fuchs C, Marshall J, Mitchell E, et al. Randomized, controlled trial of irinotecan plus infusional, bolus, or oral fluoropyrimidines in first-line treatment of metastatic colorectal cancer: results from the BICC-C Study. J Clin Oncol 2007;25:4779-86.

32. Koopman M, Antonini NF, Douma J, et al. Sequential versus combination chemotherapy with capecitabine, irinotecan, and oxaliplatin in advanced colorectal cancer (CAIRO): a phase III randomised controlled trial. Lancet 2007;370:135-42.

33. Gennatas C, Michalaki V, Gennatas S. The role of capecitabine in the management of tumors of the digestive system. Rev Rec Clin Trials 2009;4:1-11.

34. Mol L, Koopman M, Ottevanger P, Punt C. A prospective monitoring of fatal serious adverse events in a Dutch Colorectal Cancer Group (DCCG) phase III trial (CAIRO) in patients with advanced colorectal cancer. Ann Oncol 2010;21:415-8.

35. Pectasides DG, Xanthakis I, Makatsoris T, et al. Irinotecan/capecitabine (XELIRI) plus bevaciuzmab versus irinotecan/fluorouracil/leucovorin (FOLFIRI) plus bevacizumab as first-line treatment in patients with metastatic colorectal cancer: A randomized phase III trial of the Hellenic Cooperative Oncology Group (HeCOG). Proc Am Soc Clin Oncol 2010;28:7s [abstract 3541].

36. Sun W. Evolution of capecitabine dosing in colorectal cancer. Clin Colorectal Cancer 2010;1:31-9.

37. Liu G, Fransen E, Fitch MI, et al. Patient preferences for oral versus intravenous palliative chemotherapy. J Clin Oncol 1997;15:110-5.

38. Twelves C, Wong A, Nowacki MP, et al. Capecitabine as adjuvant treatment for stage III colon cancer N Engl J Med 2005;352:2696-704.

39. Dimovski AS, Angelovska-Petrusevska N, Angelovska-Grozdanovska B, et al. Predictive value of MSI, 18qLOH, TS promoter, and MTHFR C677T variants on efficacy/toxicity of capecitabine adjuvant monotherapy: A mid-term report of a prospective observational study on 136 stage II/III colon cancer patients. Proc Am Soc Clin Oncol 2010;28:7s [abstract 3521].

40. Schmoll HJ, Cartwright T, Tabernero JM, et al. Phase III trial of capecitabine plus oxaliplatin as adjuvant therapy for stage III colon cancer. J Clin Oncol 2007;25: 102-7.

41. Haller D, Tabernero J, Maroum J, et al. First efficacy findings of a randomized phase III trial of capecitabine + oxaliplatin vs bolus 5-FU/LV for stage III colon cancer (NO 16968/XELODA study). EJC Suppl 2009;7:4 [abstract 5LBA].
42. Haller DG, Cassidy J, Tabernero J, et al. Efficacy findings from a randomized phase III trial of capecitabine plus oxaliplatin versus bolus 5-FU/LV for stage III colon cancer $(\mathrm{N}=16968)$ : Impact of age on disease-free survival (DFS). Proc Am Soc Clin Oncol 2010;28:7s [abstract 3521].

43. Sauer R, Becker $H$, Hohenberger $W$, et al. Preoperative versus postoperative chemoradiotherapy for rectal cancer. N Engl J Med 2004;351:1731-40.

44. Liauw SL, Minsky BD. The use of capecitabine in the combined-modality therapy for rectal cancer. Clin Colorectal Cancer 2008;7:99-104.

45. Glynne-Jones R, Dunst J, Sebag-Montefiore D. The integration of oral capecitabine into chemoradiation regimens for locally advanced rectal cancer: how successful have we been? Ann Oncol 2006;17:361-71.

46. Dunst J, Reese T, Sutter T, et al. Phase I trial evaluating the concurrent combination of radiotherapy and capecitabine in rectal cancer. J Clin Oncol 2002;20:3983-91.

47. Ngan SY, Michael M, Mackay J, et al. A phase I trial of preoperative radiotherapy and capecitabine for locally advanced, potentially resectable rectal cancer. $\mathrm{Br}$ Cancer 2004;91:1019-24.

48. Kim JS, Kim JS, Cho MJ, et al. Preoperative chemoradiation using oral capecitabine in locally advanced rectal cancer. Int J Radiat Oncol Biol Phys 2002;54:403-8.

49. De Paoli A, Chiara S, Luppi G, et al. Capecitabine in combination with preoperative radiation therapy in locally advanced, resectable, rectal cancer: a multicentric phase II study. Ann Oncol 2006;17:246-51.

50. Krishnan S, Janjan NA, Skibber JM, et al. Phase II study of capecitabine (Xeloda) and concomitant boost radiotherapy in patients with locally advanced rectal cancer. Int J Radiat Oncol Biol Phys 2006;66:762-71.

51. Chan AK, Wong AO, Jenken DA. Preoperative capecitabine and pelvic radiation in locally advanced rectal cancer - Is it equivalent to 5-FU infusion plus leucovorin and radiotherapy? Int J Radiation Oncology Biol Phys 2010;5:1413-9.

52. Hofheinz RD, Wenz F, Post S, et al. Capecitabine (Cape) versus 5-fluorouracil (5-FU)-based (neo)-adjuvant chemoradiotherapy (CRT) for locally advanced rectal cancer (LARC): safety results of a randomized, phase III trial. Proc Am Soc Clin Oncol 2009;27:15s [abstract 4014].

53. Wang DS, Ueno $Y$, Oyamada $H$, et al. Enhancement of antitumour effect of gamma-ray irradiation in combination with camptothecin against human colorectal adenocarcinoma. Biol Pharm Bull 1996;19:354-9.

54. Klautke G, Küchenmeister U, Foitzik T, et al. Concurrent chemoradiation with capecitabine and weekly irinotecan as preoperative treatment for rectal cancer: results from a phase I/II study. Br J Cancer 2006;94:976-81.

55. Willeke F, Horisberger $\mathrm{K}$, Kraus-Tiefenbacher $\mathrm{U}$, et al. A phase II study of capecitabine and irinotecan in combination with concurrent pelvic radiotherapy (CapIri-RT) as neoadjuvant treatment of locally advanced rectal cancer. $\mathrm{Br}$ J Cancer 2007;96:912-7.

56. Cividalli A, Ceciarelli F, Livdi E, et al. Radiosensitization by oxaliplatin in a mouse adenocarcinoma: influence of treatment schedule. Int J Radiat Oncol Biol Phys 2002;52:1092-109.

57. Andre T, Boni C, Mounedji-Boudiaf L, et al. Oxaliplatin, fluorouracil, and leucovorin as adjuvant treatment for colon cancer. N Engl J Med 2004;350: 2343-51.

58. Rödel C, Grabenbauer GG, Papadopoulos T, et al. Phase I/II trial of capecitabine, oxaliplatin, and radiation for rectal cancer. J Clin Oncol 2003;21:3098-104.

59. Glynne-Jones R, Sebag-Montefiore D, Maughan TS, et al. A phase I dose escalation study of continuous oral capecitabine in combination with oxaliplatin and pelvic radiation (XELOX-RT) in patients with locally advanced rectal cancer. Ann Oncol 2006;17:50-6.

60. Machiels JP, Duck L, Honhon B, et al. Phase II study of preoperative oxaliplatin, capecitabine and external beam radiotherapy in patients with rectal cancer: the RadiOxCape study. Ann Oncol 2005;16:1898-905.

61. Chua YJ, Barbachana Y, Cunninghman D, et al. Neodajuvant capecitabine and oxaliplatin before chemoradiotherapy and total mesorectal excision in MRIdefined poor-risk rectal cancer: a phase 2 trial. Lancet Oncol 2010;11:241-8.

62. Rödel C, Liersch T, Hermann RM, et al. Multicenter phase II trial of chemoradiation with oxaliplatin for rectal cancer. J Clin Oncol 2007:25:110-7.

63. Gerard JP, Azria D, Gourgou-Bourgade S, et al. Comparison of two neoadjuvant chemoradiotherapy regimens for locally advanced rectal cancer: Results of the phase III trial ACCORD 12/0405-Prodige 2. J Clin Oncol 2010;28:1638-44.

64. Czito BG, Bendell JC, Willet CG, et al. Bevacizumab, oxaliplatin, and capecitabine with radiation therapy in rectal cancer: Phase I trial results. Int J Radiat Oncol Biol Phys 2007;68:472-8.

65. Velenik V, Omejc OM, Music M, et al. Neoadjuvant bevacizumab, capecitabine, and radiotherapy in locally advanced rectal cancer: Interim results of a phase Il CRAB trial. Proc Am Soc Clin Oncol 2010;28: Abstr. 14006.

66. Machiels JP, Sempoux C, Scalliat P, et al. Phase I/II study of preoperative cetuximab, capecitabine, and external beam radiotherapy in patients with rectal cancer. Ann Oncol 2007;18:738-44.

67. Hofheinz RD, Horisberger K, Woernle C, et al. Phase I trial of cetuximab in combination with capecitabine, weekly irinotecan, and radiotherapy as neoadjuvant therapy for rectal cancer. Int J Radiat Oncol Biol Phys 2006;66:1384-90.

68. Rödel C, Arnold D, Hipp M, et al. Phase I-II trial of cetuximab, capecitabine, 
oxaliplatin, and radiotherapy as preoperative treatment in rectal cancer. Int J Radat Oncol Biol Phys 2007;70:1081-6.

69. Krause M, Ostermann G, Petersen C, et al. Decreased repopulation as well as increased reoxygenation contribute to the improvement in local control after targeting the EGFR by C225 during fractionated irradiation. Radiother Oncol 2005;76:162-7.

70. Glynne-Jones R, Mawdsley S, Harrison M. cetuximab and chemoradiation for rectal cancer - is the water getting muddy? Acta Oncol 2010;49:278-86.

71. Morelli P, Cascone T, Troiani T, et al. Sequence-dependent antiproliferative effects of cytotoxic drugs and epidermal growth factor receptor inhibitors. Ann Oncol 2005(Suppl 4):iv61-8.
72. Jonsson M, Ekstrand A, Edekling T, et al. Experiences from treatment-predictive KRAS testing; high mutation frequency in rectal cancers from females and concurrent mutations in the same tumour. BMC Clin Pathol 2009;9:1-5.

73. Bengala C, Betelli S, Bertolini F, et al. Epidermal growth factor receptor gene copy number, K-ras mutation and pathological response to preoperative cetuximab, 5 -FU and radiation therapy in locally advanced rectal cancer. Ann Oncol 2009; 20:469-74.

74. Werd S, Keltenthaler E, Cowen J, et al. The clinical end economic benefit of capecitabine and tegafur with uracil in metastatic colorectal cancer. Br J Cancer 2006;95:27-34. 